\title{
CLASSIFICATION OF VEGETATION OF LOWER TANAWAL, PAKISTAN BY CLUSTER ANALYSIS ON THE BASIS OF ALTITUDE
}

\author{
Adeela Bibi ${ }^{1 凶}$, Zafar Iqbal ${ }^{1}$, Ghulam Mujtaba Shah ${ }^{1}$, Sarfaraz Nawaz ${ }^{2}$ \\ Department of Botany, Hazara University Mansehra-21300, Pakistan \\ Department of Botany, Government Post Graduate College Abbottabad, Pakistan
}

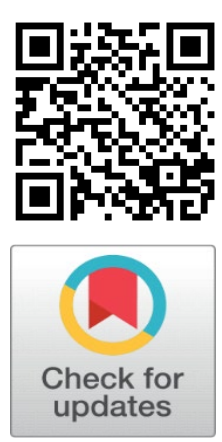

Received 3 December 2021

Accepted 1 January 2022

Published 31 January 2022

\section{CorrespondingAuthor \\ Adeela Bibi, \\ adeelabibiresearch@gmail.com \\ DOI \\ 10.29121/granthaalayah.v10.i1.2022 4454}

Funding: This research received no specific grant from any funding agency in the public, commercial, or not-for-profit sectors.

Copyright: (C) 2022 The Author(s). This is an open access article distributed under the terms of the Creative Commons Attribution License, which permits unrestricted use, distribution, and reproduction in any medium, provided the original author and source are credited.

\section{ABSTRACT}

During this research study on the basis of altitude 5 altitudinal ranges were formed from 2396 to $6742 \mathrm{ft}$. from Lower Tanawal, Abbottabad Pakistan. From these 05 altitudinal ranges 17 plant communities were established, 3 plant communities were documented from altitudinal range I (2396-3054 ft). Four plant communities were formed from altitudinal range II (3142-3613 ft). Three plant communities were recognized from altitudinal range III (3708-4182 ft). Four plant communities were recorded from altitudinal range IV (4220-4666 ft). Three plant communities were established from altitudinal range $V$ (4827-6742 ft). The ordination techniques Two-way Indicator Species Analysis (TWINSPAN) were used to classify the data.

Keywords: TWINSPAN, Vegetation, Cluster Analysis, Lower Tanawal

\section{INTRODUCTION}

Cluster analysis is a classification technique for placing similar objects into clusters. The cluster analysis is used to place similar samples into clusters, which are arranged in a hierarchical structure called a dendrogram. Clustering is the process of data by combining similar objects to form small classes, then combining small classes into larger classes Pielou (1984). Cluster analysis was used to form and identify similar groups among sampling units, to classify the sampling units into numerous groups according to similar vegetation structure, Hoon (2010).

\section{Study Area}

The Lower Tanawal located in District Abbottabad Khyber-Pakhtunkhwa Pakistan. It lies between the $34^{\circ} 12^{\prime} 32$ and $34^{\circ} 15^{\prime} 76$ north latitude to $73^{\circ} 09^{\prime}$ 398 and $73^{\circ} 03^{\prime} 316$ east longitudes Bibi et al. (2019). The Lower Tanawal is part of the Lesser Himalayas. The Lesser Himalayas comprise on whole area of Hazara division Hussain and Illahi (1991). 


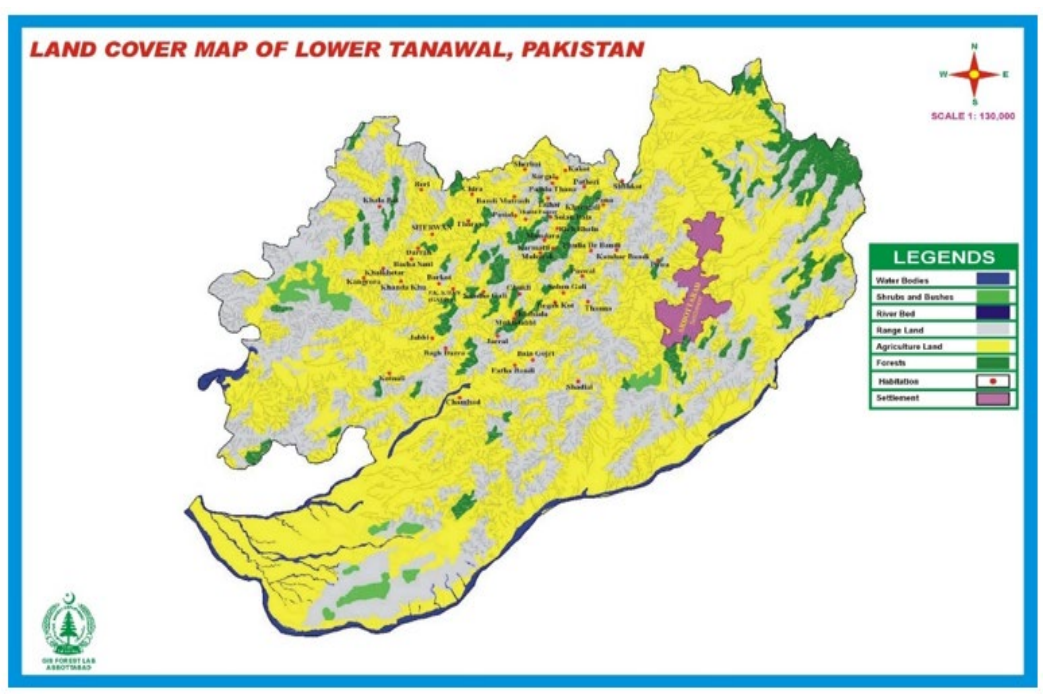

Figure 1 Map of Lower Tanawal Showing Location of Stands

TWINSPAN were used for the classification of samples and species. In this classification 9 stands and 72 species were observed. The data was classified into two groups. In division 1 the eigenvalue 0.40 was noted. Seven stands were placed in negative group $\left({ }^{*} 0\right)$ whereas two stands were in positive group $\left({ }^{*} 1\right)$. In division 2 the eigenvalue was 0.43 . In division 2 (7) 1 stand was positioned in negative group $\left({ }^{*} 00\right)$ whereas 7 stands were positioned in positive group $\left({ }^{*} 01\right)$. Then based on indicator species 3 plant communities Eucalyptus-Cannabis-Justicia community, Dodonaea-Carissa-Olea community and Acacia-Pyrus-Olea were documented from altitudinal range 2396-3054 ft (Figure 2).

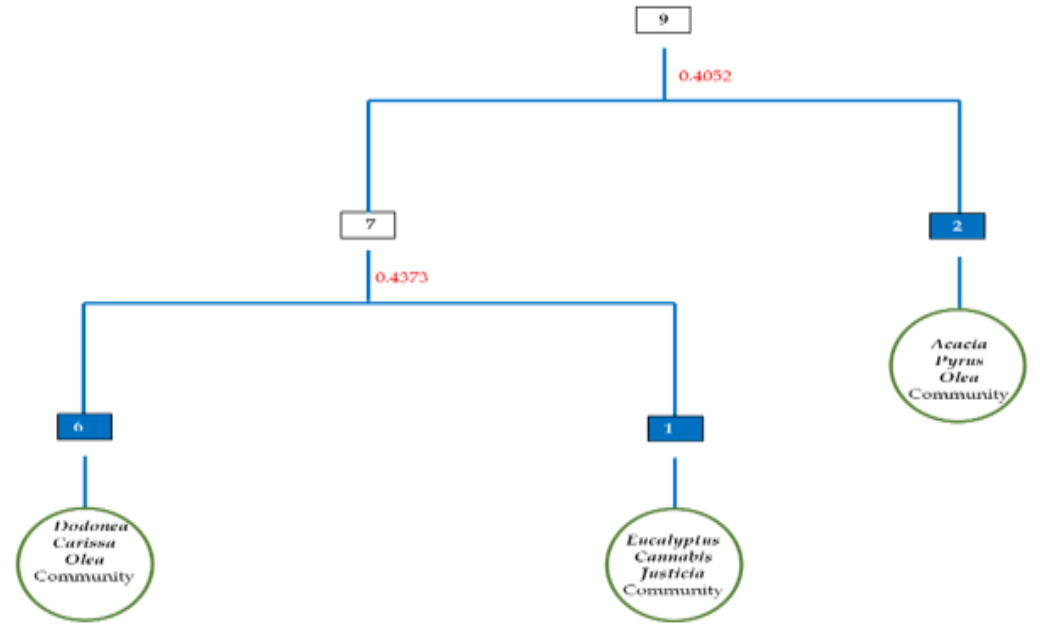

Figure 2 TWINSPAN Classification of vegetation from the Altitudinal Range I of Lower Tanawal, Pakistan

\section{Cluster Analysis of the Altitudinal Range 1}

The Cluster Analyses was done by using the method of PC-ORD version 5 which converted 9 stands into 3 plant communities (Figure 3 ). 


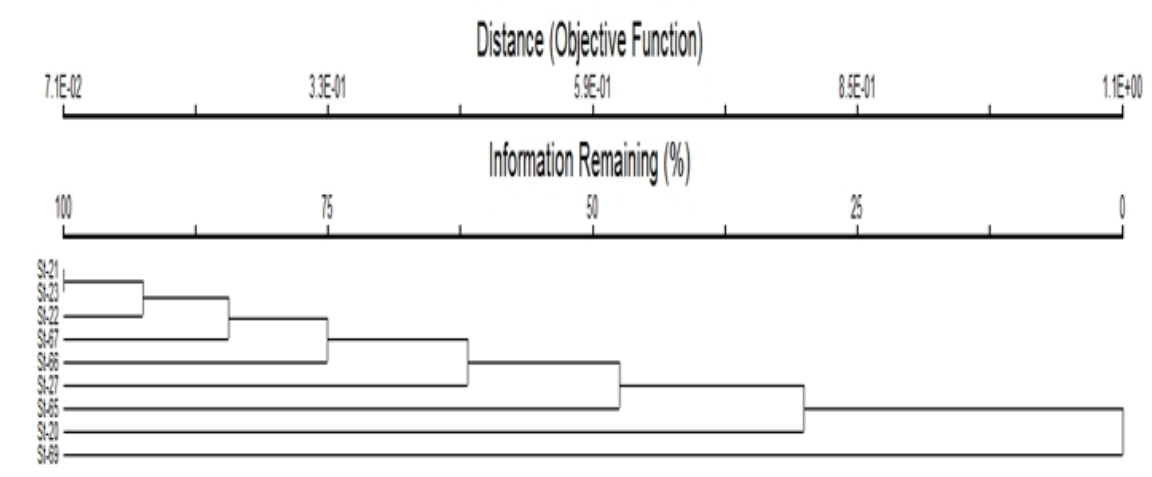

Figure 3 Cluster analysis of the vegetation of Altitudinal Range I of Lower Tanawal, Pakistan

\section{Two-Way Cluster Analysis}

The two-way cluster analysis showed distribution of plant species into different stands. The dandrogram identified the presence and absence of plant species in different stands. The black dots have presented the presence while white bubbles shown absence of species in the stands. TWCA dandrogram shown that Dodonaea viscose was present in 08 stands out of 09 stands whereas Ziziphus nummularia was present in 07 stands which showed wide range of distribution of these species at an altitudinal range 2396-3054 ft whereas Asparagus officinalis, Morus alba, Anagallis arvensis, Lantana camara, Opuntia ovata and Xanthium stromarium present in one stand which indicated narrow range of distribution of these species at altitudinal range1. Three plant communities were recognized from 09 stands having 72 plants species (Figure 4).

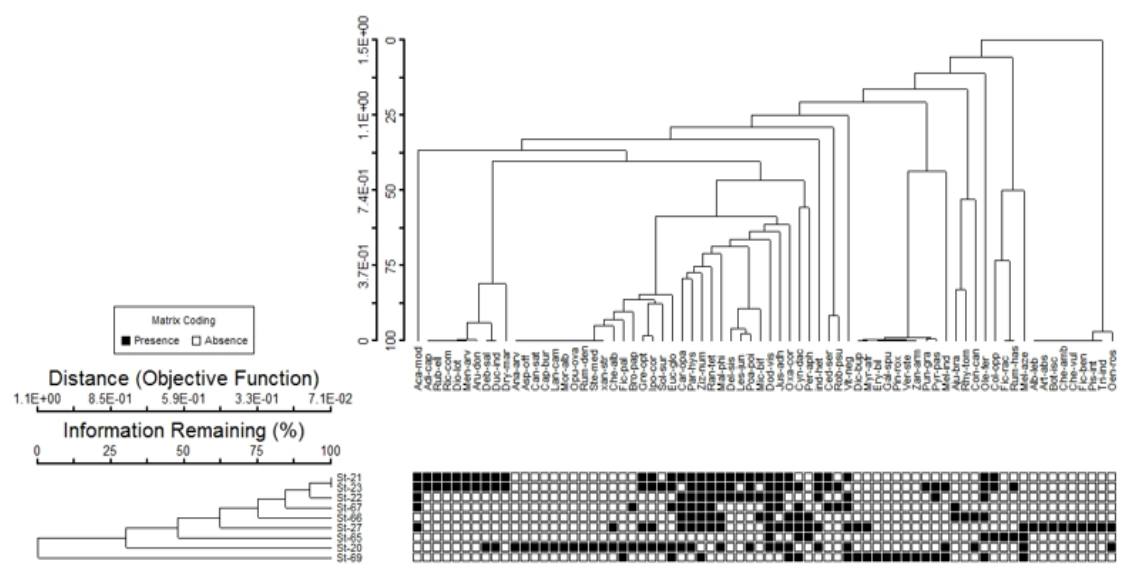

Figure 4 Two Way Cluster Analyses of the vegetation of Altitudinal Range I of Lower Tanawal, Pakistan

\section{Eucalyptus-Cannabis-Justicia Community}

Eucalyptus globulus, Cannabis sativa and Justicia adhatoda community were noted from locality of Khan Thathera at the elevation of $3054 \mathrm{ft}$. In this community 01 stand and 32 plant species were noted. In this community Eucalyptus globulus with IV (8.66), Cannabis sativa IV (8.24) and Justicia adhatoda IV (7.50) were dominant plant species. At this elevation temperature was 36.4 , wind speed 0.3 , humidity 40.1, dew point 22.3, Heat index 38.5 and barometer pressure was 853.2. Soil of this locality was clay loam. 


\section{Dodonaea-Carissa-Olea Community}

Dodonea viscosa, Carissa opaca and Olea ferruginea community were noted from Khalabut, Thathi Kamila, Beri, Chamhad, Fateh Bandi and Shadial between the elevations of 2396-3025 ft. This community has 06 stands and 128 plant species. The dominant plant was Dodonaea viscosa having IV (21.12), Carissa opaca, IV (7.84) and Olea ferruginea IV (6.48). At these elevations temperature range was 33.4 to 37.2 wind speed 0.1 to 0.3 humidity 34.3 to 40.2 , dew point 16.1 to 22.3 , Heat index 23.7 to 38.5 and barometer pressure was 831.2 to 865.2 . Soil of these localities was loam.

\section{Acacia-Pyrus-Olea Community}

This community was recorded from Bachha Sani and Purani Patheri between elevations of 2522-3014 ft. This community has 02 stands and 40 plant species. The dominant plant species in this community were Acacia modesta with IV (9.54) Pyrus pashia (8.65) and Olea ferruginea (5.71). In these two localities temperature range was 35.1 to 37.2 wind speed 0.1 to 0.3 humidity 34.3 to 39.2 , dew point 16.1 to 24.3 , Heat index 23.7 to 36.5 and barometer pressure was 831.2 to 867.2. Soil of these localities was loam.

\section{Species Area Curve}

Species area curve describes the relationship between number of species and number of stands. PC-ORD version 5 was used to draw species area curve. It indicated that with an increase in the number of stands the number of species also increases. The diagram indicated that stand 6 shown maximum numbers of species up to stand 9 when number of species increase the species curve distance become zero (Figure 5).

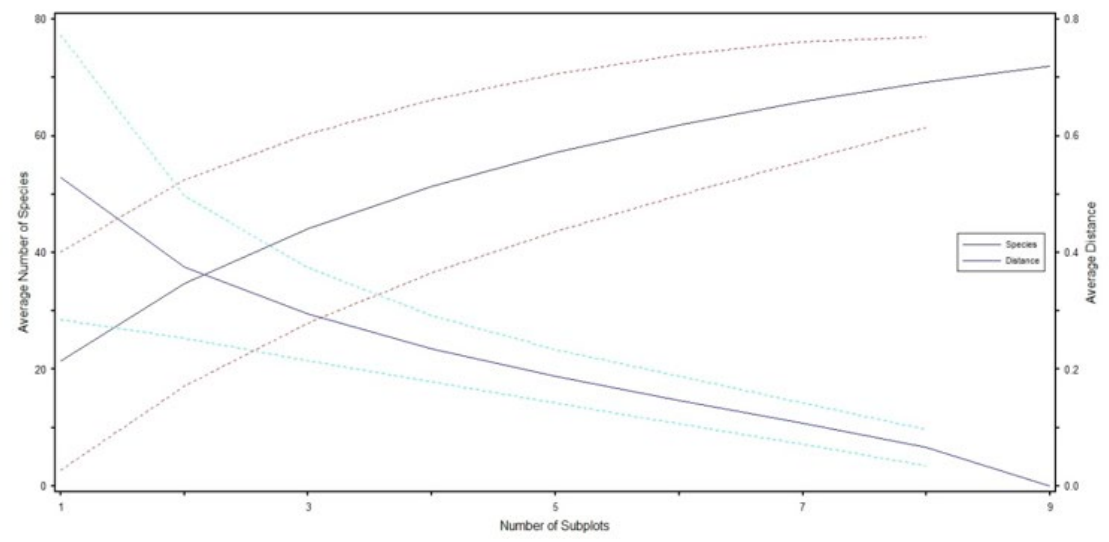

Figure 5 Species area curve of the vegetation of Altitudinal Range 1 of Lower Tanawal, Pakistan

\section{TWINSPAN Classification of the Altitudinal Range II (3142- $3613 \mathrm{ft}$.)}

There were 10 stands and 115 species. The data were classified into two groups. In division 1 the eigenvalue was 0.48 . Eight stands were positioned in negative group $\left({ }^{*} 0\right)$ whereas 2 stands were placed in positive group $\left({ }^{*} 1\right)$. The eigenvalue was 0.35 in division 2 . In division 2 (8) 1 stand was positioned in negative group $\left({ }^{*} 00\right)$ while 7 stands were positioned in positive group $\left({ }^{*} 01\right)$. The eigenvalue was 0.31 in division 3 (7). In this division 2 stands were positioned in 
negative group $(* 10)$ while 5 stands were located in positive group $\left({ }^{*} 11\right)$. The 04 plant communities Dodonaea-Ficus-Carissa community, Acacia-Arundo-Asparagus community, Dodonaea-Cynodon-Olea community, and Broussonetia-Olea-Pinus community were formed (Figure 6).

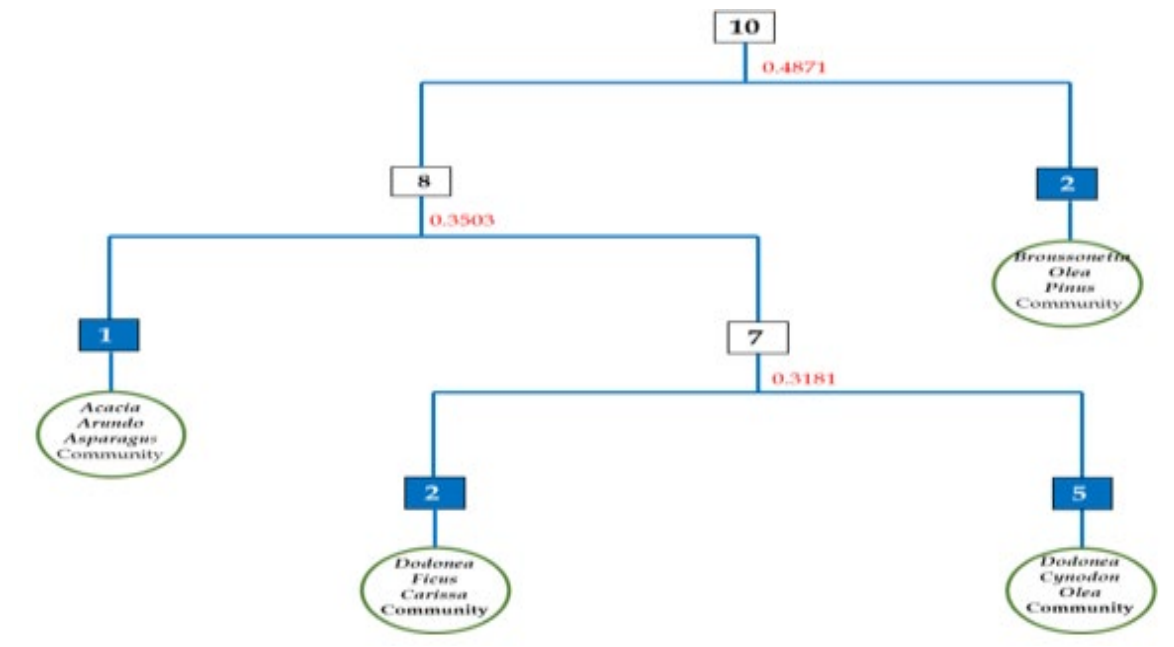

Figure 6 TWINSPAN Classification of vegetation from the Altitudinal Range II of Lower Tanawal, Pakistan

\section{Cluster Analysis of the Altitudinal Range II}

The Cluster Analysis was done which shown cluster of 10 stands into 04 plant communities (Figure 7).

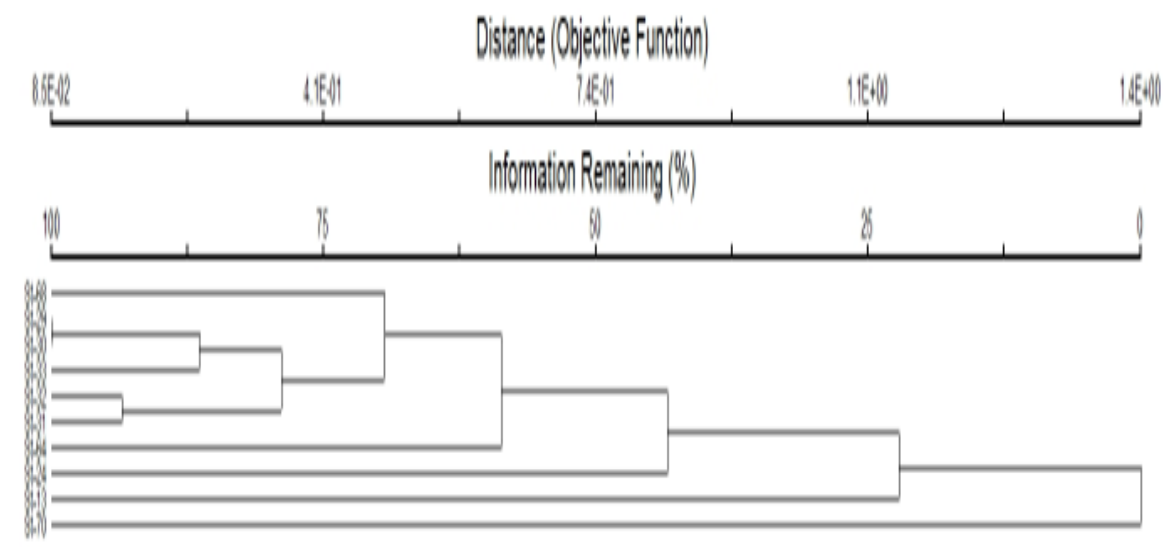

Figure 7 Cluster analysis of the vegetation of Altitudinal Range II of Lower Tanawal, Pakistan

\section{Two-Way Cluster Analyses}

The two-way cluster analysis showed distribution of plant species into different stands on the basis of presence and absence $(1,0)$. The two-way cluster analysis dandrogram indicated that Oxalis corniculata was present in 10 stands and Cynodon dactylon was present in 09 stands which shown wide range of distribution of these species at an altitudinal range 3142 to $3613 \mathrm{ft}$, whereas Trifolium repens, Viburnum cotinifolium, Ipomoea carnea, Mirabilis jalapa, Sedum sarmentosum, Senecio aquaticus and Scrophularia dentate were present in 01 stand which indicated narrow range of distribution of these species from altitudinal range II. The following four plant communities were recognized from 10 stands with 115 species (Figure 8). 


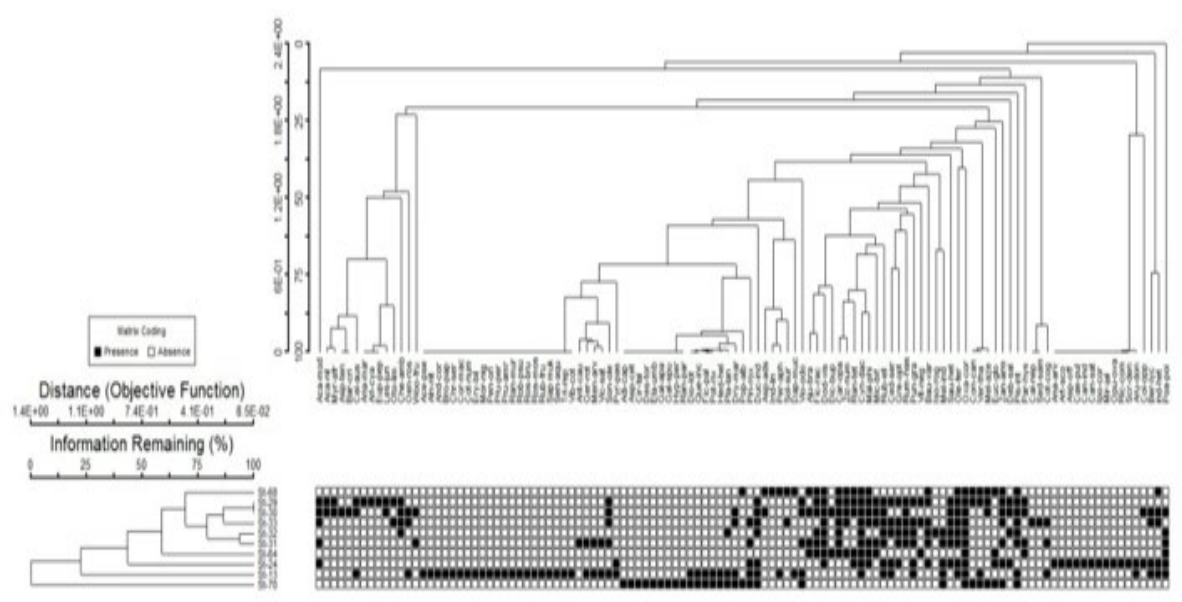

Figure 8 Two Way Cluster Analyses of the vegetation of Altitudinal Range II of Lower Tanawal, Pakistan

\section{Dodonaea- Ficus-Carissa Community}

This community was recognized from Chamhad and Chakar Pain between the elevations of 3142-3202 ft. In this community 02 stands and 37 plant species were noted. Dodonaea viscosa with IV (15.87) Ficus palmata, (5.30) and Carissa opaca (4.96) were the dominant species. At these elevations temperature range was 34.4 to 37.5 wind speed 0.1 to 0.3 humidity 34.3 to 54.2 , dew point 22.3 to 23.5 , Heat index 23.7 to 35.5 and barometer pressure was 831.2 to 857. 2. Soil of these localities was loam.

\section{Acacia-Arundo-Asparagus Community}

This community was documented from Banseri at the elevations of $3468 \mathrm{ft}$. In this community 01 stand and 21 plant species were documented. Acacia modesta have IV (48.45), Arundo donex, (8.07) Asparagus officinalis (8.05) were the dominant species. At this elevation temperature range was 32.2, wind speed 0.1, humidity 34.1, dew point 26.1, Heat index 24.7 and barometer pressure was 832.2. Soil of these localities was loam.

\section{Dodonaea-Cynodon-Olea Community}

This community was recorded from Bandi Darah, Jabbi, Naradoga, Thalian, and Khuliala between the elevations of 3327-3613 ft. In this community total 05 stands and 151 species were recognized. Dodonaea viscosa with IV (13.57), Cynodon dactylon (8.50) and Olea ferruginea (4.71) were the dominant species. At these elevations temperature range was 33.4 to 37.2 wind speed 0.1 to 0.3 humidity 34.1 to 40.2 , dew point 25.7 to 27.3 , Heat index 37.3 to 38.5 and barometer pressure was 823.2 to 854.2 . Soil of these localities was loam.

\section{Broussonetia-Olea-Pinus Community}

This community was noted from Shahkot and Kamhar bandi between elevations of 3353-3418 ft. In this community 02 stands and 78 plant species were noted. Broussonetia papyrifera having IV (19.63), Olea ferruginea (4.42), Pinus roxburghii (3.99) were the dominant species. At these elevations temperature range was 28.3. to 32.2 wind speed 0.2 to 0.3 humidity 33.3 to 35.2 , dew point 13.9 to 22.3 , 
Heat index 30.2 to 36.5 and barometer pressure was 865.2 to 899.2. Soil of these localities was loam.

\section{Species Area Curve}

Species area curve describes the relationship between number of stands and number of species. It states that when number of stands increasing the plant species also increase. The diagram indicates that stand 5 indicated maximum numbers of plant species up to stand 10 (Figure 9).

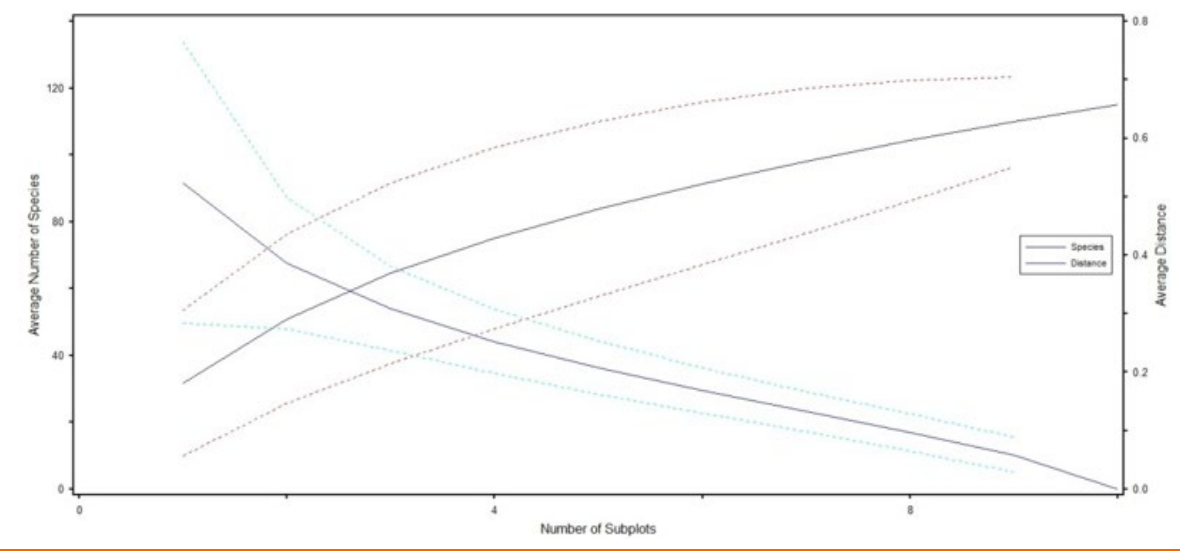

Figure 9 Species area curve of the vegetation of Altitudinal Range 1I of Lower Tanawal, Pakistan

\section{TWINSPAN Classification of the Altitudinal Range III (3708- $4182 \mathrm{ft}$.)}

In this classification 17 stands and 182 species were recorded. The data were classified into two groups. In division 1 the eigenvalue was 0.31 . The 13 stands were placed in negative grouped $\left({ }^{*} 0\right)$ while 04 stands were positioned in positive group $\left({ }^{*} 1\right)$. In division $2(13) 7$ stands were positioned in negative group $\left({ }^{*} 00\right)$ whereas 6 stands were placed in positive group $\left({ }^{*} 01\right)$ and in this division the eigenvalue was 0.25 . Then 3 plant communities Prunus-Pinus-Dodonea community, Pinus-PunicaDodonaea community and Dodonaea-Acacia-Cynodon community were recognized (Figure 10).

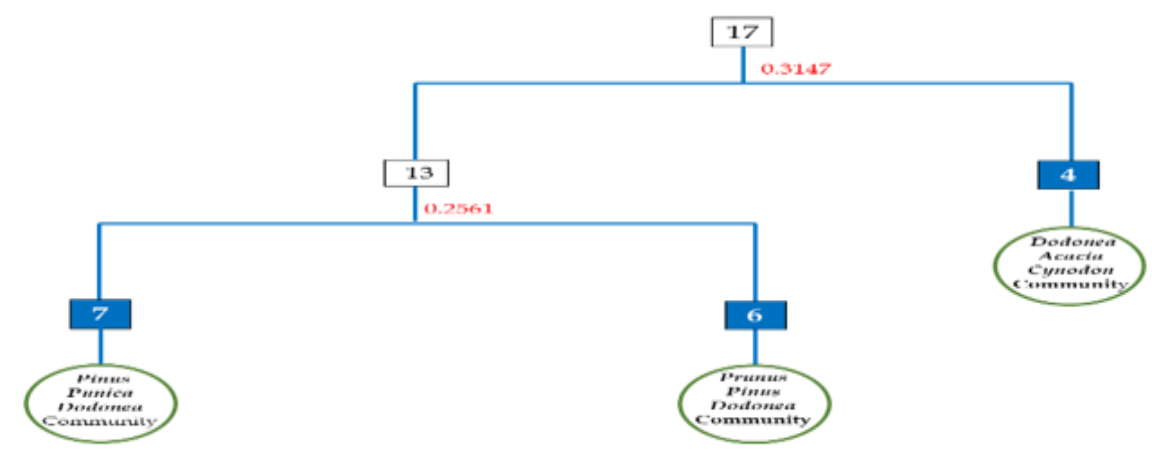

Figure 10 TWINSPAN Classification of vegetation from the Altitudinal Range III of Lower Tanawal, Pakistan

\section{Cluster Analysis of the Altitudinal Range III}

The Cluster Analyses by using PC-ORD was done which grouped 17 stands into 3 plant community having 182 plants species (Figure 11). 


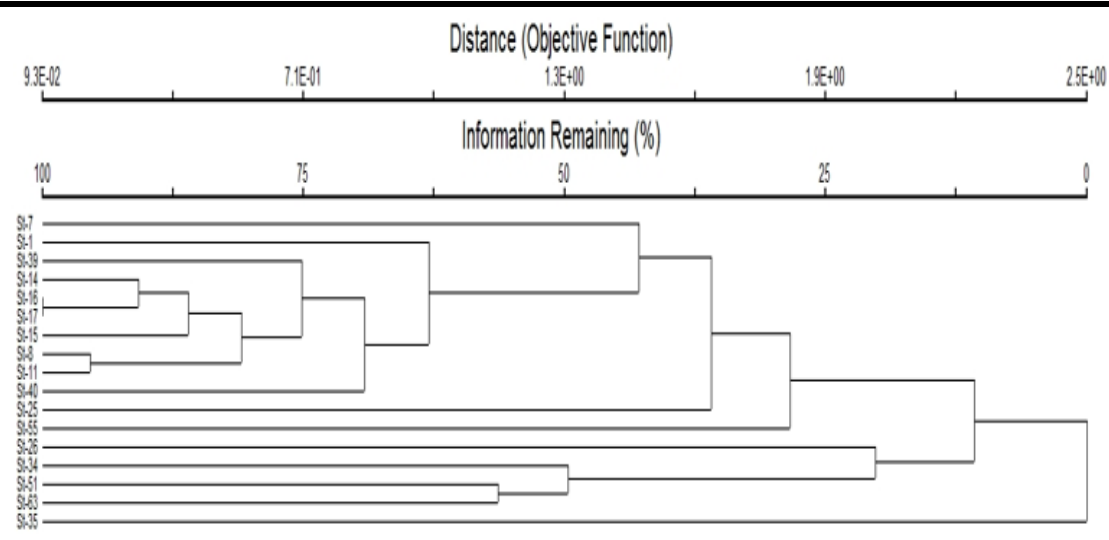

Figure 11 Cluster analysis of the vegetation of Altitudinal Range III of Lower Tanawal, Pakistan

\section{Prunus-Pinus-Dodonea Community}

It was recorded from Siyal, Sherwan Khurd, Thoray, Kakot, Rakran and Gali Syedan between elevations of 3708-4152 ft. There were 6 stands and 107 species. Prunus amricana IV (26.64) Pinus roxburghii (6.23) and Dodonaea viscosa (5.23) were the dominant species. At these elevations temperature range was 34.3 to 35.2 wind speed 0.1 to 0.2 humidity 33.3 to 42.2 , dew point 13.8 to 22.3 , Heat index 29.2 to 33.5 and barometer pressure was 865.2 to 887.2 . Soil of these localities was clay loam.

\section{Pinus-Punica-Dodonaea Community}

This community was noted from Garamri and Patheri between elevations of 3892-4182 ft. In this community 07 stands and 122 plant species were noted. Pinus roxburghii IV (5.77) Punica granatum (4.77) Dodonaea viscosa with IV (4.54) were the dominant plant species. At these elevations temperature range was 28.4. to 32.2 wind speed 1.1 to 0.3 humidity 39.3 to 42.2 , dew point 17.9 to 22.3 , Heat index 30.2 to 34.5 and barometer pressure was 861.2 to 885.2 . Soil of these localities was loam.

\section{Dodonaea-Acacia-Cynodon Community}

This community was recognized between elevations of 3789-4161 ft. from Kotnali, Jabri, and Mukdabi. There were 04 stands and 72 plant species. Dodonaea viscosa have IV (17.57), Acacia modesta (11.66) and Cynodon dactylon with IV (6.83) were the dominant plant species. At these elevations temperature range was 29.3 to 34.2 , wind speed 0.1 to 0.2 , humidity 33.3 to 39.2 , dew point 13.9 to 21.3 , Heat index 33.2 to 37.5 and barometer pressure was 833.2 to 866.2 . Soil of these localities was loam.

\section{Species Area Curve}

It states that when number of stands increasing the plant species also increase. The diagram showed that after stand 8 maximum number of plant species appear, and new species continuously appear up to stand 17 (Figure 12). 


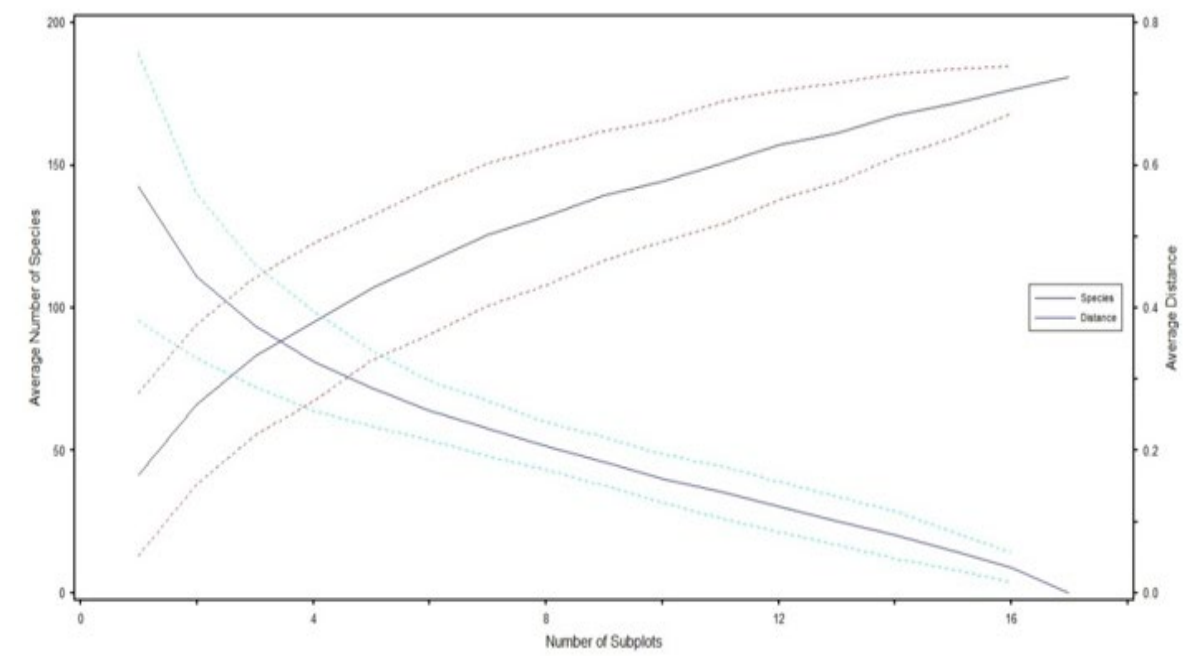

Figure 12 Species area curve of the vegetation of Altitudinal Range III (3708-4182 ft.) of Lower Tanawal, Pakistan

\section{TWINSPAN Classification of the Altitudinal Range IV (4220- $4666 \mathrm{ft}$.)}

This classification had shown 35 stands and 201 plant species. The data were classified into two groups. Twenty-eight stands were positioned in negative group $\left({ }^{*} 0\right)$ while seven stands were positioned in positive group $\left({ }^{*} 1\right)$. The eigenvalue was 0.22 in division 1 . In division 2 (28) 14 stands were placed in negative group $\left({ }^{*} 00\right)$ while 14 stands were placed in positive group $\left({ }^{*} 01\right)$. The eigenvalue was 0.21 in division 2. In division 3 (7) 6 stands were placed in negative group $\left({ }^{*} 00\right)$ while 1 stand was placed in positive group $\left({ }^{*} 01\right)$. The eigenvalue was 0.52 in division 3. Then 4 plant communities Pinus-Punica-Olea community Debregessia-Punica-Oxalis community, Dodonaea-Pinus-Olea community and Polygonum-Rubus-Mentha community were formed (Figure 13).

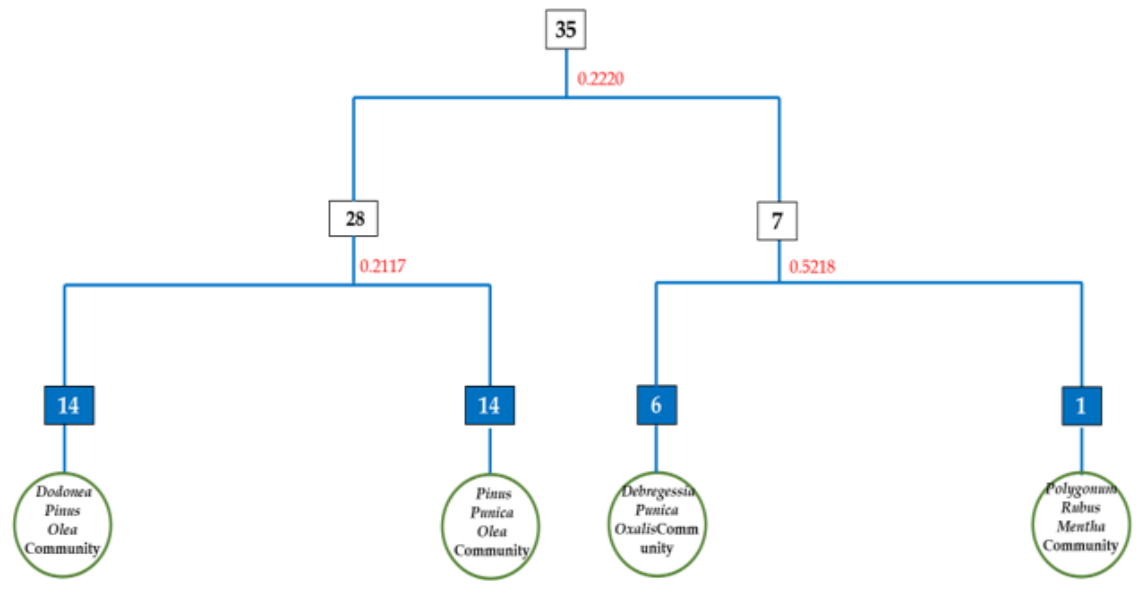

Figure 13 TWINSPAN Classification of vegetation from the Altitudinal Range IV of Lower Tanawal, Pakistan

\section{Cluster Analysis of the Altitudinal Range IV}

In this Cluster Analyses 35 stands grouping into 4 plant communities were observed (Figure 14). 


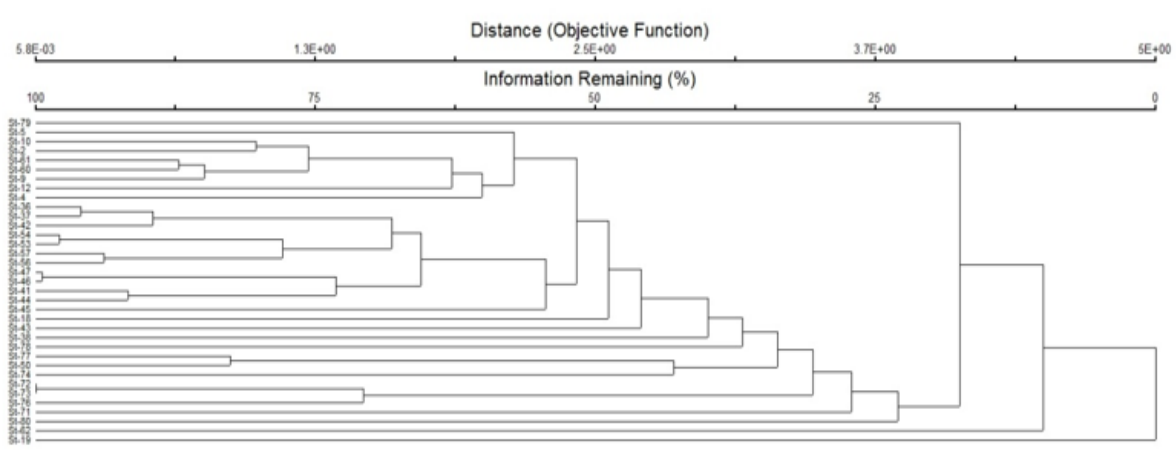

Figure 14 Cluster analysis of the vegetation of Altitudinal Range IV of Lower Tanawal, Pakistan

\section{Two-Way Cluster Analyses}

In this analysis four plant communities were documented from 35 stands with 201 species. The TWCA dandrogram indicated that Olea ferruginea, Berberis lycium, Punica granatum, were present in more than 20 stands while Caryopteris odorata, Symplocos recemosa, Gymnosporia royleana and Polygala vulgris present in one stand which indicated narrow range of distribution of these species in an elevation 4220 to $4666 \mathrm{ft}$ (Figure 15).

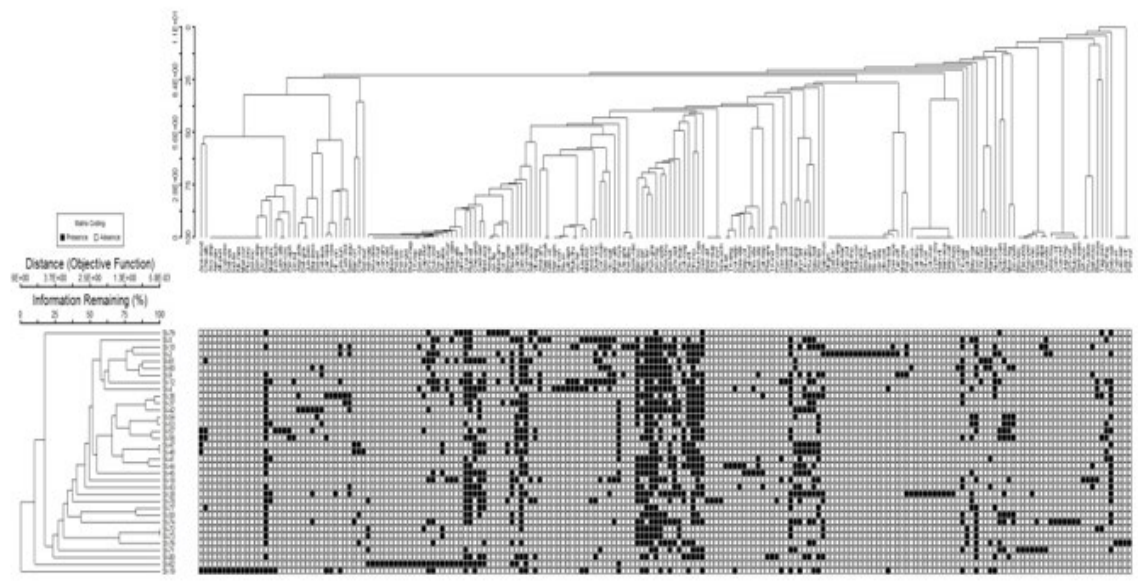

Figure 15 Two Way Cluster Analyses of the vegetation of Altitudinal Range IV of Lower Tanawal, Pakistan

\section{Pinus-Punica-Olea Community}

This community was documented from Takia Hal, Sargal, Pawa, Khanda Khoo, Pindkargu, Patiyan, Sherwan Kalan, Thathi Faqeer Sab, Panduthana, Poona, Soban Gali and Chetri, between elevations of 4267-4666 ft. This community has 14 stands and 123 plant species. The dominant plant species were Pinus roxburghii with IV (7.20) Punica granatum (6.09) and Olea ferruginea with IV (5.14). Soil of these localities was loam. At these elevations temperature range was 29.3 to 34.2, wind speed 0.1 to 0.2 , humidity 32.3 to 38.2 , dew point 12.9 to 21.3 , Heat index 33.2 to 36.5 and barometer pressure was 831.2 to 865.2 .

\section{Debregessia-Punica-Oxalis Community}

This community was noted from Mundarra, Panduthana,Karmatti, Thathi Faqeer Sb, Mubaraak and Patheri Sydan at an elevations of 4220-4629 ft. This community have 06 stands and 108 plant species. The dominant plant species were 
Debregessia salicifolia with IV (5.27) Punica granatum (3.93) and Oxalis corniculata with IV (3.44). Soil of these localities was clay loam. At these elevations temperature range was 29.3 to 34.2 , wind speed 0.1 to 0.2 , humidity 33.3 to 39.2 , dew point 13.9 to 21.3 , Heat index 33.2 to 37.5 and barometer pressure was 831.2 to 866.2.

\section{Dodonaea-Pinus-Olea Community}

This community was noted from Kotha Doga, Panduthana, Sargal, Sando Gali, Darah, Bain Gojre, Soben Galli, Panyali, Habibabad, Kangrora, Khalkhater, and Chariala, between elevations of $4239-4533 \mathrm{ft}$. This community have 14 stands and 105 plant species. The dominant plant species were Dodonaea viscosa with IV (19.96) Pinus roxburghii (11.10) and Olea ferruginea (5.23). Soil of these localities was loam. At these elevations temperature range was 29.3 to 34.2 , wind speed 0.1 to 0.2 , humidity 33.3 to 38.2 , dew point 13.9 to 21.3 , Heat index 33.2 to 36.5 and barometer pressure was 834.2 to 866.2 .

\section{Polygonum-Rubus-Mentha Community}

This community was noted from elevation of $4385 \mathrm{ft}$. In this community, 01 stand and 28 plant species were noted. The dominant plant species were Polygonum viviparum (43.84), Rubus ellipticus (38.14) and Mentha longifolia (37.93). Soil of these localities was clay loam. At these elevations temperature range was 29.3 to 32.2 , wind speed 0.1 to 0.2 , humidity 33.3 to 37.2 , dew point 13.9 to 21.3 , Heat index 33.2 to 36.5 and barometer pressure was 833.2 to 867.2 .

\section{Species Area Curve}

The diagram indicated that after stand 15 maximum number of species appear and new species continuously appear up to stand 35 (Figure 16).

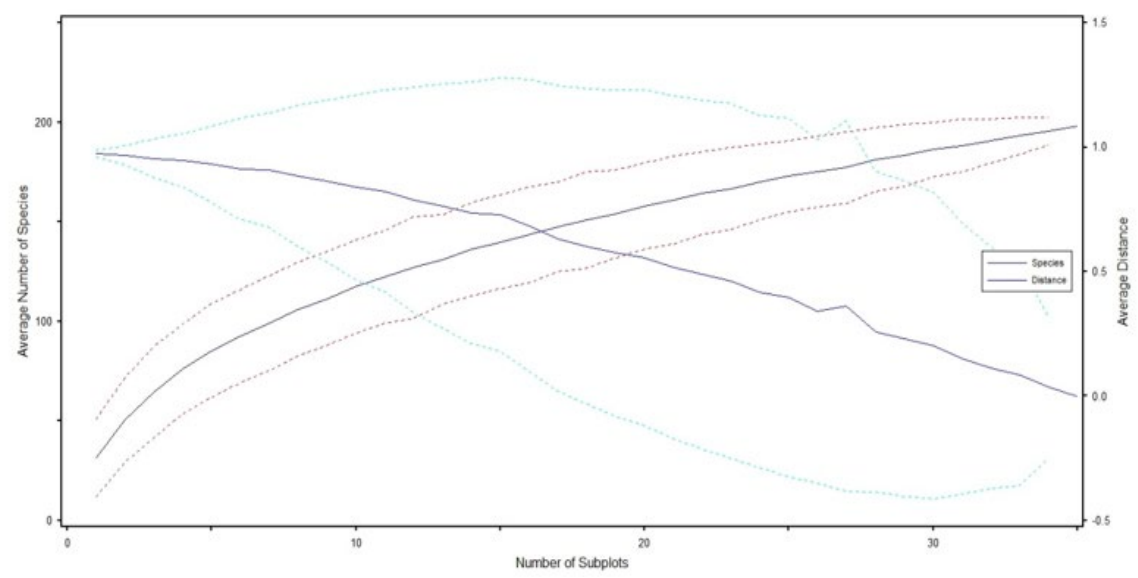

Figure 16 Species area curve of the vegetation of Altitudinal Range IV of Lower Tanawal, Pakistan

\section{TWINSPAN Classification of the Altitudinal Range V (4827- $6742 \mathrm{ft}$.)}

This classification has 101 plant species and 9 stands. The data were classified into 02 groups. In division 01 the eigenvalue was 0.54 and 07 stands were placed in negative groups $(* 0)$ while 02 stands were placed in positive group $(* 1)$. In division 02 (7) 1 stand was placed in negative group $\left({ }^{*} 00\right)$ while 06 stands were placed in positive group $\left({ }^{*} 01\right)$. In division 02 the eigenvalue was 0.50 . The 3 plant 
communities Pinus-Punica-Pistacia community, Pinus-Polygala-Chenopodium community and Dodonaea-Acacia-Acacia community were formed. (Figure 17).

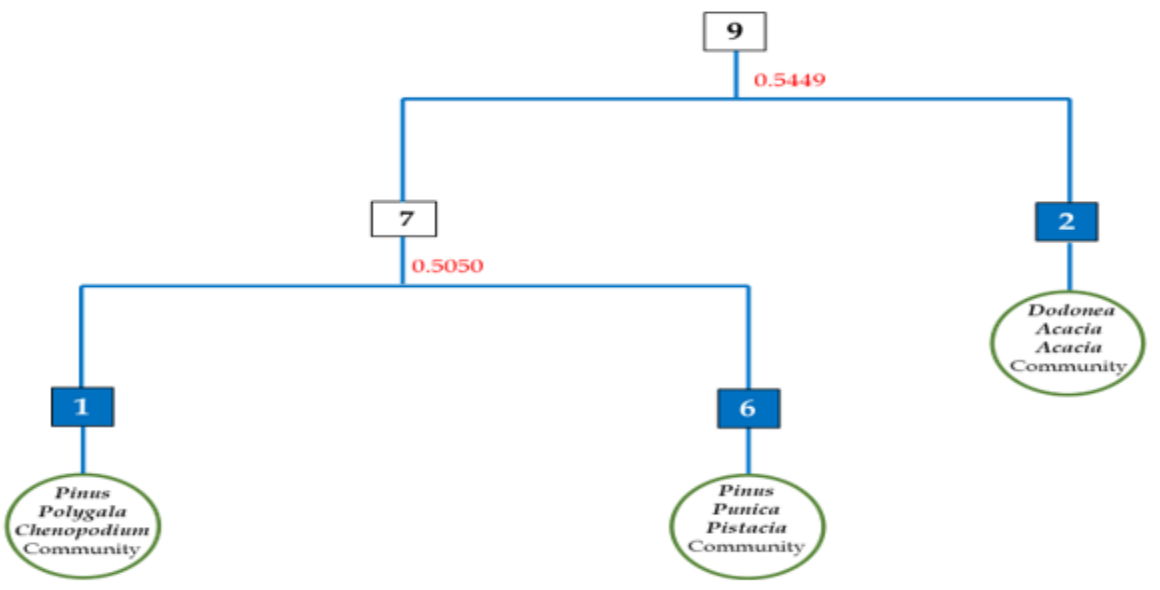

Figure 17 TWINSPAN Classification of vegetation from the Altitudinal Range V of Lower Tanawal, Pakistan

\section{Cluster Analysis of the Altitudinal Range V}

The Cluster Analyses classified 9 stands into 3 plant communities (Figure 18).

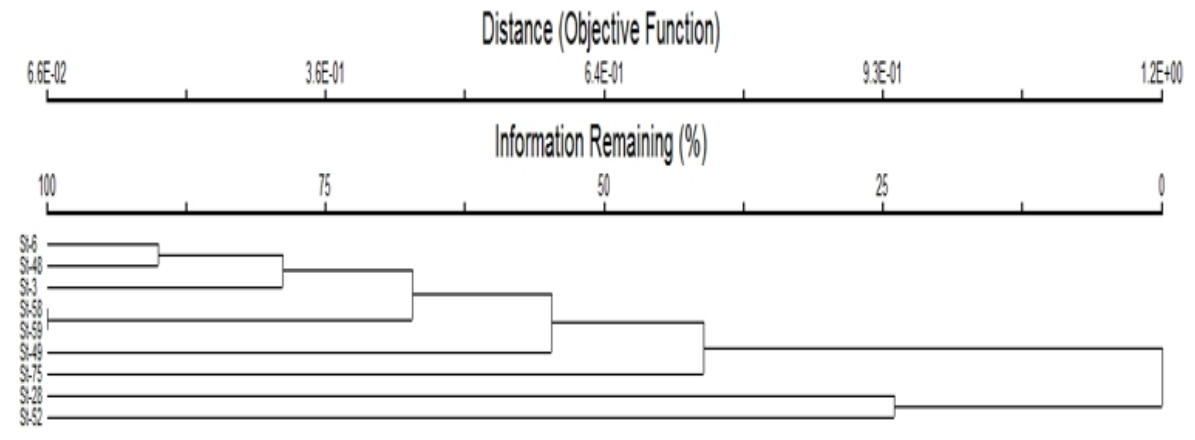

Figure 18 Cluster analysis of the vegetation of Altitudinal Range V of Lower Tanawal, Pakistan

\section{Two-Way Cluster Analyses}

The dandrogram showed that Isodon rugosus and Berberis lycium, were present in 07 stands while, Trichodesma indicum, Cissampelos pareira, Acacia mearnsii, Delbergia sisso, Indigofera linifolia, Tridax procumbens and Cotoneaster melanocarpus were present in 01 stand which indicated narrow range of distribution of these species. At these elevations temperature range was 29.3 to 34.2 , wind speed 0.1 to 0.2 , humidity 33.3 to 39.2 , dew point 13.9 to 21.3 , Heat index 33.2 to 37.5 and barometer pressure was 833.2 to 866.2 .

Three plant communities were documented from 09 stands having 101 plants species (Figure 19). 


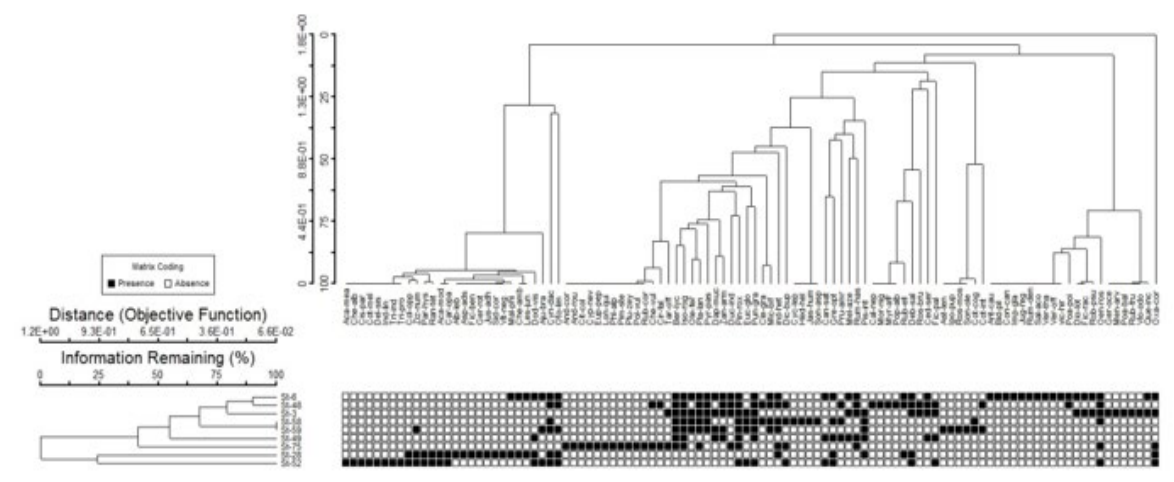

Figure 19 Two Way Cluster Analyses of the vegetation of Altitudinal Range V of Lower Tanawal, Pakistan

\section{Pinus-Punica-Pistacia Community}

In this community 06 stand and 73 plant species were noted. Pinus roxburghi with IV (15.84), Punica granatum (5.57), Pistacia integerrima (5.55), were dominant. This community was noted from the localities of Bagarian, Thana, Paswal, Sandogali and Thallay between the elevations of 4827-5480 ft. Soil of these localities was clay loam. At these elevations temperature range was 30.1 to 34.2 , wind speed 0.2 to 0.3 , humidity 32.3 to 39.2 , dew point 13.9 to 18.3 , Heat index 33.2 to 37.5 and barometer pressure was 834.2 to 867.2 .

\section{Pinus-Polygala-Chenopodium Community}

Pinus roxburghii, Polygala vulgaris, Chenopodium vulgare community were noted at the elevations of $6742 \mathrm{ft}$. In this community there were 01 stand and 24 plant species. Pinus roxburghi (34.13) Polygala vulgaris (7.36) Chenopodium vulgare (5.71) were dominant plant species. Soil of these localities was loam. At these elevations temperature range was 29.3 to 33.2 , wind speed 0.1 to 0.2 , humidity 34.3 to 39.2 , dew point 13.9 to 21.3 , Heat index 32.2 to 37.5 and barometer pressure was 833.2 to 888.2. At these elevations temperature range was 29.3 to 34.2 , wind speed 0.1 to 0.2 , humidity 33.3 to 39.2 , dew point 13.9 to 21.3 , Heat index 33.2 to 37.5 and barometer pressure was 833.2 to 866.2 .

\section{Dodonea-Acacia-Acacia Community}

This community was documented from Todomira, Jarral between the elevations of 4952-5357 ft. This community has 02 stand and 39 species. Dodonaea viscosa with IV (11.00), Acacia modesta (7.13) and Acacia mearnsii (6.79) were the dominant species. Soil of these localities was clay loam. At these elevations temperature range was 29.3 to 34.2 , wind speed 0.1 to 0.2 , humidity 33.3 to 39.2 , dew point 13.9 to 21.3 , Heat index 33.2 to 37.5 .

\section{Species Area Curve}

The diagram indicated that stand 05 shown maximum number of plant species up to stand 09 (Figure 20). 


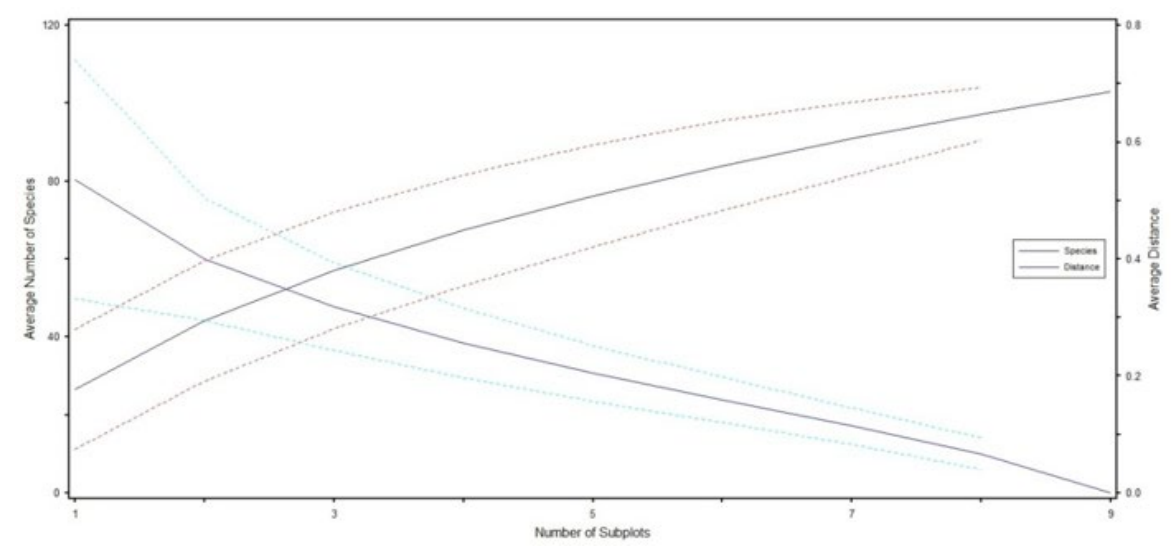

Figure 20 Species area curve of the vegetation of Altitudinal Range V of Lower Tanawal, Pakistan

\section{AVERAGE SPECIES RICHNESS AND DIVERSITY INDEX}

From the 5 altitudinal range average species richness and average species diversity were noted. The maximum species richness (18.56) was noted from the altitudinal range 2396-3054.Minimum species richness (4.44) was noted from altitudinal range 4827-6742. The maximum diversity index (0.88) was documented from 4220-4666. Minimum diversity index 0.27 was recorded from 3142-3613 (Figure 21).

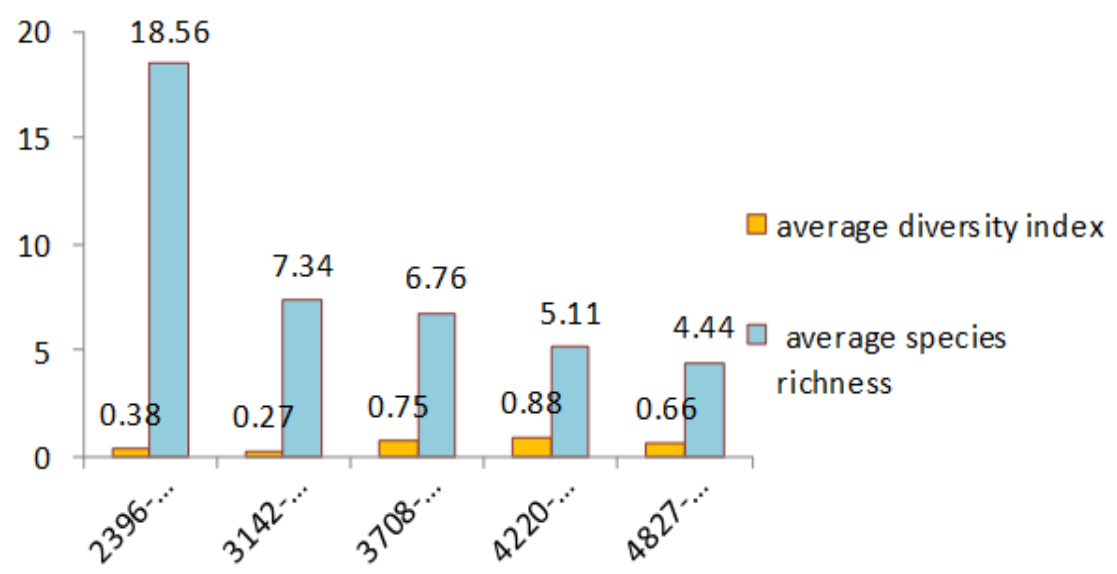

Figure 21 Average diversity index and species richness with altitude

\section{DISCUSSION}

TWINSPAN were used for the classification communities on the basis of altitudinal ranges. The two-way cluster analysis shown the distribution of plant species into numerous stands based on presence and absence of species. Five altitudinal ranges were formed, and 17 communities were documented from these altitudinal ranges. From altitudinal range 2396-3054 ft. from 09 stands with 72 species 03 plant communities were documented. Result shown that Dodonaea viscosa have wide range of distribution due to presence in maximum stands of this altitudinal range.

From altitudinal range 3142-3613 ft. 04 communities were documented from 10 stands and 115 plant species. Result shown that Oxalis corniculata and Cynodon dactylon indicated wide range of distribution in this range. At this range (3708-4182 $\mathrm{ft}$.) 03 communities were recognized with 182 species from 17 stands. 
At altitudinal range (4220-4666 ft.) 04 plant communities from 35 stands with 201 plant species were noted. The result shown that Olea ferruginea and Punica granatum have wide range of distribution. From altitudinal range 4827-6742 ft 03 communities were formed from 9 stands with 101 plant species. The result shown Isodon rugosus showed wide range of distribution. Ahmed et al. (2009a) noted that cluster analysis classified different plant communities in Himalayan Forest of Pakistan. The similar findings were showed by Mehmood et al. (2015) who documented 06 plant communities by using cluster analysis and TWCA in the forest of District Torghar. Our results are agreed with Bokhari et al. (2016) who stated 06 associations by using cluster analyses in Pine Forest of Azad Kashmir. Our results are similar to Amjad et al. (2014a) who described 13 plant communities which merged in to 04 plant associations by using cluster analysis. These results are also in line with Ahmed et al. (2010) who stated 03 plant groups from forest of Azad Kashmir by using cluster analysis. Our results are agreed with Baruch (2005) who documented many plant communities and merged them into few groups by using cluster analysis.

From the altitudinal range 2396-3054 ft. maximum species richness (18.56) was documented. The minimum species richness (4.44) was noted from altitudinal range 4827-6742 ft. The maximum diversity index (0.88) was documented from 4220-4666 ft. Minimum diversity index 0.27 was noted from 3142-3613 ft. Our results are agreed with Malik et al. (2003) who identified that at higher altitude there were high species diversity and at lower altitude low species diversity was recorded in the area of Dao Khun, Kashmir. Our findings are also similar with Malik et al. (2012) who noted that diversity and altitude have correlation in Bedori Hills and Ganga Choti of Azad Jummu and Kashmir. Many phytosociological studies showed that with altitude species richness decreased Currie and Francis (2004), Brown and Lomolino (1998).

\section{REFERENCES}

Ahmed, M., N. Khan, M. Wahab, S. Hamza, M.F. Siddique, K. Nizim and M.U. Khan. (2009a). Vegetation structure of Olea ferruginea forests of lower Dir District of Pakistan. Pak. J. Bot., 40(6) : 2683-2695. Retrieved from https://www.cabdirect.org/cabdirect/abstract/20103234322

Amjad, M. S., M. Arshad, A. Rashid, S. K. Chaudhari, N. Z. Malik and S. Fatima. (2014a). Examining relationship between environmental gradients and 234 Lesser Himalyan forest vegetation of Nikyal valley, Azad Jammu and Kashmir using ordination analysis. Asi. Pac. J. Trop. Med., 7 (Suppl 1) : 610-616. Retrieved from https://doi.org/10.1016/S1995-7645(14)60297-2

Bibi, A. Z. Iqbal, G.M. Shah. (2019). Floristic diversity, biological spectrum of Lower Tanawal, KP, Pakistan. Ukr. J. Ecol., 4 (9) : 505-514. Retrieved from https://doi.org/10.15421/2019_782

Bokhari, T. Z., Y. Liu, M. Ahmed, M. F. Siddiqui, Q. Li and Z. U. Khan. (2016). Multivariate analysis of some pine forested areas of Azad Kashmir, Pakistan. Pak. J. Bot., 48(1) : 105-113.

Bokhari, T. Z., Y. Liu, M. Ahmed, M. F. Siddiqui, Q. Li, Z. U. Khan and S. A. Malik. (2016). Multivariate analysis of some pine forested areas of Azad Kashmir, Pakistan. Pak. J. Bot., 48(1) : 105-113.

Brown, J.H. and M.V. Lomolino. (1998). Biogeography.2nd Ed. Sunderland, Massachusetts (Sinauer Associates, Inc. Publishers). pp.691. Retrieved from 
https://academic.oup.com/jmammal/article/80/4/1385/852047?login=tr ue

Currie, D.J. and A.P. Francis. (2004). Regional versus climate effect on taxon richness in angiosperms ; reply to Qian and Ricklefs. Am. Nat.,163(5) : 780-785. Retrieved from https://doi.org/10.1086/383596

Hoon,s (2010) The Classification of Forest Communities by Cluster Analysis in Mt. Seokbyung Experimental Forest of Gangwon-Do Jour. Korean For. Soc. Vol. 99, No. 5, pp. 736 743. Retrieved from https://www.koreascience.or.kr/article/JAK0201034952232541.page

Hussain, F., and I. Illahi. (1991). Ecology and Vegetation of Lesser Himalayan Pakistan. Botany Department University of Peshawar, pp. 187.

Malik, Z.H., F. Hussain and N.Z. Malik. (2012). Life form and leaf size spectra of plant communities Harbouring Ganga Chotti and Bedori Hills during 1999-2000. Int. J. Agric. Biol., 9(6) : 833-838. Retrieved from https://www.researchgate.net/profile/Z-

Malik/publication/242139950_Life_form_and_Leaf_Size_Spectra_of_Plant_ Communities_Harbouring_Ganga_Chotti_and_Bedori_Hills_During_19992000/links/55769f7108ae7521586c3590/Life-form-and-Leaf-SizeSpectra-of-Plant-Communities-Harbouring-Ganga-Chotti-and-Bedori-HillsDuring-1999-2000.pdf

Mehmood. A., A.H. Shah., S.M. Khan, A.H. Shah, I. Rehman and H. Ahmad. (2015). First floristic exploration of the district Tor Ghar, Khyber Pakhtunkhwa, Pakistan. Pak. J. Bot., 47(SI) : 57-70. Retrieved from https://www.researchgate.net/profile/AzharMehmood/publication/301625823_FIRST_FLORISTIC_EXPLORATION_OF_ THE_DISTRICT_TORGHAR_KHYBER_PAKHTUNKHWA_PAKISTAN/links /57 1e495d08aead26e71a8614/FIRST-FLORISTIC-EXPLORATION-OF-THEDISTRICT-TORGHAR-KHYBER-PAKHTUNKHWA-PAKISTAN.pdf

Pielou, E.C. (1984). The interpretation of ecological data- A primer on classification and ordination. John Wiley and Sons. USA 